\title{
Myoglobinuria, 1984
}

\author{
Lewis P. Rowland
}

This paper was originally presented in June 1982 at the XVII Canadian Congress of Neurological Sciences in Toronto, Ontario where Dr. Rowland was the distinguished guest of the Canadian Neurological Society.

Can. J. Neurol. Sci. 1984;11:1-13

The year is included in the title of this review because the subject is the diversity of conditions that result in myoglobinuria, and new causes keep appearing as conditions in society change or new drugs are introduced. The syndrome is often linked to seamier aspects of society or medicine: war; sadistic drill sergeants; drug abuse; attempted suicide; self-medication or inadequate supervision of drug therapy. On the other hand, study of myoglobinuric syndromes has informed us about new hereditable biochemical causes and we have learned more about the action of viruses on muscle.

The numerous causes of myoglobinuria and the renal effects capture the attention of physicians in many different medical specialties. The condition was once thought to be rare; 20 years ago, there were only 150 recorded cases (Rowland et al., 1964). Now myoglobinuria is recognized as a major cause of renal failure, accounting for 5-25\% of all cases of acute renal failure (Anderson et al., 1977; Grossman et al., 1974; Koffler et al., 1976). My own interest has been sustained by the research of three illustrious members of our department, Salvatore DiMauro (1979), Audrey S. Penn (1980) and Joseph Willner (1981); each is concerned with a different group of diseases, but all are linked to myoglobinuria.

\section{Definition of a Clinical Syndrome:}

Here is an irony. Nephrologists focus not on the kidney but on muscle; they use the term "rhabdomyolysis". Students of muscle disease turn the other way, look at the urine, and call the same syndrome "myoglobinuria". Why the difference?

We can only surmise possible answers. Myologists understand that the major threat of the disorder is renal failure but they may be more interested in understanding how the muscle injury arises, and that can be done best by splitting one muscle disorder from the others, looking for common or distinguishing features. To nephrologists, however, muscle injury is muscle injury; the nature of the injury may be less important to them than the end result, acute renal failure.

There are other reasons, of course. Nephrologists point out that myoglobin need not be demonstrated in the urine to make the diagnosis and they note that many constituents of muscle other than myoglobin are also released in the process and may also be important in the pathogenesis of the renal disorder (Bowden et al., 1956). However, there is reason to believe that myoglobin (like hemoglobin) is the major nephrotoxin released from muscle (Braun et al., 1976). Also, clinical myoglobinuria does not occur without muscle necrosis; "rhabdomyolysis" has been nothing more than a synonym for myoglobinuria for decades.

Rarely, rhabdomyolysis has been used in another sense, as a histologic diagnosis, but the old-fashioned term "muscle necrosis" suffices for that purpose and without ambiguity. No pathologist could look at an unidentified muscle section and proclaim a histologic diagnosis of rhabdomyolysis. No new term was ever needed to supplant "muscle necrosis".

"Rhabdomyolysis" is presumably analogous to "hemolysis" by lysis of red blood cells is a general process while muscle necrosis is often focal (Schmitt et al., 1983). Besides, hemolysis has been studied thoroughly and there is no strictly analogous disorder in muscle. "Rhabdomyolysis" conveys an unwarranted aura of precision and implies a uniform process in different cases, but muscle necrosis, with or without myoglobinuria, can result from any of numerous diverse causes (Stringer et al., 1972).

For years, there has been a kind of lexical standoff; authors have been free to use either term and the problem of terminology has never been discussed. Redundancies such as "rhabdomyolysis with myoglobinuria" have somehow become popular, and "nontraumatic rhabdomyolysis"' (Akmal and Massry, 1983; Chaikan, 1980; Chugh et al., 1979; Grossman etal., 1974; Koffler et al., 1976) has been used incomprehensibly to include the modern version of the crush syndrome in comatose patients (which is as traumatic as it could possibly be) and exerciseinduced syndromes (in which trauma is probably important).

"Rhabdomyolysis" was never formally defined until Gabow et al. (1982) used it to designate any condition in which serum creatine kinase (CK) activity was more than five times normal (in the absence of brain or heart disease). In our hospital, that would mean anyone with a serum CK of 250 units. In contrast, patients with Duchenne muscular dystrophy or polymyositis often have values between 5,000 and 10,000; even higher values, up to 50,000 or more, are characteristic of attacks of myoglobinuria. Patients with Duchenne dystrophy do not have overt

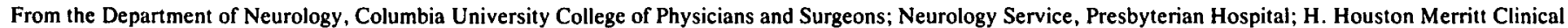
Research Center for Muscular Dystrophy and Related Diseases, and the General Clinical Research Center, Columbia-Presbyterian Medical Center.

Supported by Center grants from NINCDS (NS-11766-09A1) the Muscular Dystrophy Association, and NIH (RR 00645)

Reprint requests to: Lewis Rowland, M.D., Neurological Institute, 710 West 168th Street, New York, New York 10032 
myoglobinuria except as a reaction to succinylcholine or halothane; whether and why Duchenne patients might be especially susceptible to these drugs are important questions that should not be buried by using the same term (rhabdomyolysis) for both the general state of Duchenne patients and their acute reactions to anesthesia (Rowland, 1983; Willner and Nakagawa, in press).

On the other hand, CK values about 500 are commonly encountered in asymptomatic individuals for unknown reasons and of no practical consequence, a situation we have called "idiopathic hyperCKemia"; similar values occur often in athletes after conventional exertion. Gabow et al., (1982) must have encountered similar patients; $26 \%$ of their cases had negative tests for heme pigment in urine. To lump the mild exertional rise of CK with frank attacks of myoglobinuria by calling both "rhabdomyolysis" would be analogous to making no distinction between angina and myocardial infarction, or between transient ischemic attacks and cerebral infarction or hemorrhage. All cases of increased serum CK activity do not have the same disorder in muscle (Rowland, 1980; Jones et al., 1983).

"Myoglobinuria" therefore seems to be the much more preferable term but it, too, must be defined. Within the past decade, the widespread use of radioimmunoassay has identified normal myoglobin levels of up to $100 \mathrm{ng} / \mathrm{ml}$ in serum, and other immunologic technics can detect similarly small amounts in urine of asympotmatic individuals after exercise or myocardial infarction (Table 1). The syndrome of concern, however, is a clinical disorder, not just a biochemical state; it is not recognized by "abnormal levels" of myoglobin that may be detected by these sensitive tests. Rather, it is identified by the following conditions:

1. In the least controversial situation, the patient is alert, notes myalgia or limb weakness, and the urine is unequivocally darker than normal. The urine give positive chemical tests for both albumin and heme (a concentration at least $4 \mathrm{u} / \mathrm{ml}$ ) but there are few or no red blood cells; casts are often present and may include the pigment. The urinary pigment is identified as myoglobin an an immunochemical method or by electrophoresis. Serum content of CK and other sarcoplasmic enzymes is high, usually more than 100 times the upper limit of normal (but it is difficult to set an arbitrary limit). Hyperuricemia, hyperphosphatemia and hypo- or hypercalcemia are inconstant features; if there is renal failure, serum potassium and calcium levels may rise.

2. If the patient is comatose, or if the presenting disorder is one of acute renal failure, there may be no muscle symptoms or signs. In these cases, the diagnosis can be made without even examining urine if two conditions are met: 1) The serum content of sarcoplasmic enzymes is about 100 times normal. 2) There is renal failure. (In the absence of renal failure, it is not likely that serum enzymes values of this magnitude would even occur without heme-positive reactions in urine). Usually, the cause of the syndrome can also be discerned; extreme muscular exertion and prolonged coma are probably the most common causes but there are many others, as indicated in the following paragraphs.

\section{A Classification of Myoglobinuria Based on Pathogenesis}

A functional classification of myoglobinuria best begins with a division into hereditary and sporadic forms because recognition of the hereditable enzyme abnormalities suggests modes of pathogenesis (Tables 2, 3). However, there is often more than
Table 1: Sensitivity of Tests for Myoglobinuria

\begin{tabular}{lr}
\hline \hline & $\underline{\mathbf{n g} / \mathbf{m l}}$ \\
Visible Pigmenturia & 250,000 \\
Dipstick (Orthotolidine Reagent) & 4,000 \\
Immunodiffusion & 4,000 \\
Hemagglutination Microcomplement Fixation & 300 \\
Radioimmune Assay & 5 \\
\hline
\end{tabular}

Data from Adams et al. (1978); Donald (1978); Kagen (1978); Karlsson et al. (1978); Knochel (1982); Malvano et al. (1978); Markowitz and Wobig (1977); Sarachak and Bernstein (1974); Stone et al. (1975).

\section{Table 2: The Diverse Causes of Myoglobinuria: Hereditable Diseases}

\begin{tabular}{|c|c|}
\hline Enzyme Abnormality Known & $\begin{array}{l}\text { Phosphorylase (McArdle) } \\
\text { Phosphofructokinase (Tarui- } \\
\text { Layzer) } \\
\text { Phosphoglycerate kinase } \\
\text { (DiMauro) } \\
\text { Phosphoglycerate mutase } \\
\text { (DiMauro) } \\
\text { Lactate dehydrogenase (Kanno) } \\
\text { Palmityl carnitine transferase } \\
\text { (DiMauro) }\end{array}$ \\
\hline Incompletely Characterized & $\begin{array}{l}\text { Excess lactate production } \\
\text { (Larsson) } \\
\text { Impaired fatty acid oxidation(?) } \\
\text { (Engel) } \\
\text { Impaired function of sarcoplasmic } \\
\text { reticulum (?) (Familial } \\
\text { malignant hyperthermia) }\end{array}$ \\
\hline Uncharacterized & $\begin{array}{l}\text { Familial, biochemical abnormality } \\
\text { unknown } \\
\text { Repeated attacks in an individual }\end{array}$ \\
\hline
\end{tabular}

one cause in each attack. For instance, hereditable myoglobinuria is usually induced by exercise but sometimes infection and fever are responsible. Sporadic myoglobinuria may also be induced by exertion, with no recognized genetic disorder.

The complex nature of individual attacks is illustrated by drug-induced coma; crushing injury is not the only disorder because the sedative drug may also depress cellular metabolism in muscle, brain and other organs. Cerebral depression is followed by inadequate ventilation, leading to hypoxia and respiratory acidosis. Concomitantly, shock and metabolic acidosis follow tissue injury and lead to heme-induced renal failure, which further aggravates the already complex metabolic disorder. (It is believed that myoglobin does not injure the kidney unless there is also shock, impaired renal perfusion, and acidosis.) Myoglobinuria due to drug-induced coma is therefore related to the drug, trauma and several other factors as well.

Multiple causes may be involved in other cases, too. For instance, some drug-induced syndromes involve agitation and fever, as well as possible drug effects directly on muscle. In some exertional cases, it may not be possible to determine whether fever resulted from myoglobinuria or whether heat 
stroke caused the muscle damage. That is why the same "cause" may appear in more than one category of the accompanying tables. Despite these complexities, it is possible to separate the numerous causes of myoglobinuria for purposes of discussion.

\section{Hereditable Myoglobinuria}

A decade ago, there were only two identified hereditable causes: lack of phosphorylase or lack of phosphofructokinase (Rowland and Penn, 1972). Now, six enzyme disorders have been recognized; five affect glycogenolysis or glycolysis and one involves lipid metabolism (DiMauro, 1979; DiMauro et al., 1973, 1982, 1983; Kanno et al., 1980). In all six, there is a disorder of muscle energy metabolism and it can be suspected that maintenance of muscle surface membranes fails when ATP levels fall below some critical level. However, this has not been proven. In rats, iodoacetate can impair the replenishment of ATP in working muscle and this can lead to two symptoms, muscle contracture and myoglobinuria (Brumback et al., 1983). In humans, however, phosphorylase-deficient muscle was exercised during contracture and there was no change in total intracellular ATP content (Rowland et al., 1965). Failure to demonstrate the expected drop in ATP was unexplained but could have been due to regeneration of the nucleotide during the process of freezing the tissue, which required a few seconds. However, more rapid freezing in later studies gave similar results (Edwards et al., 1980) and so did an NMR study that avoided freezing altogether (Ross et al., 1981). These methods would not detect a change in ATP that was restricted to one intracellular compartment (such as sarcoplasmic reticulum) but there is no evidence of such focal intracellular change of ATP in any other condition. It is therefore not proven that a drop in ATP causes contracture or, by extension, an attack of myoglobinuria but it is still the most logical explanation.

The biochemical abnormality in these genetic disorders is permanent but attacks of myoglobinuria are intermittent. The provoking factor is almost always exercise and, except for the hemolytic anemia that accompanies lack of phosphofructokinase or phosphoglycerate kinase, it is difficult to predict a patient's specific biochemical abnormality on clinical grounds. Patients lacking carnitine palmityl transferase activity may be more likely to have attacks if they miss a meal before commencing vigorous exercise; in the original pair of brothers, one attack was provoked by overoptimism on a fishing trip and they went without eating before taking a long hike back from the water, carrying an empty basket. Taking a meal before anticipated exercise and other measures designed to raise blood glucose levels have also been recommended to patients with the other genetic myoglobinurias; the results have been inconsistent, almost never dramatic. Literally, patients learn to live with these diseases by limiting physical activity. Exercise-induced attacks may be linked to the energy crisis in muscle, but even in familial cases, attacks are sometimes induced by fever or infection and that mechanism is obscure.

DiMauro (1979) has pointed to other unexplained features of these diseases. Although all are congenital as well as inherited, symptoms never start before adolescence despite the considerable running and jumping of childhood. Also, the number of men affected seems excessive, even considering the greater likelihood of men to indulge in vigorous muscular activity, but there is no suggestion of an X-linked disorder except for phosphoglycerate kinase.
Table 3: The Diverse Causes of Myoglobinuria: Sporadic (Aquired) Disorders

A. Exertion

1. Military training, wrestling, squat jump or situp exercises, long distance running, skiing.

2. Anterior tibial syndrome.

3. Convulsions (status epilepticus).

4. Agitated delerium, restraints.

5. High voltage electric shock, lightning stroke.

6. Status asthmaticus.

7. Prolonged myoclonus or acute dystonia.

B. Crush

1. Compression by fallen weights.

2. Compression by body in prolonged coma.

C. Ischemic

1. Occlusion of major artery.

2. Ischemia in compression or anterior tibial syndromes.

3. Coagulopathy in sickle cell disease or syndromes with disseminated intravascular coagulation.

4. Ligation of vena cava.

D. Metabolic Depression or Distortion

1. Carbon monoxide, barbiturates, narcotics.

2. Diabetic ketoacidosis.

3. Nonketotic hyperglycemia hyperosmolar states.

4. Renal tubular acidosis.

5. Hypernatremia.

6. Hyponatremia.

7. Hypokalemia (see table 3).

8. Hypophosphatemia

a. Intravenous fluid therapy for acute and chronic alcohol abuse.

b. Diabetic ketoacidosis.

c. Parathyroidectomy.

E. Drugs and toxins (See table 4)

F. Abnormalities of Body Temperature

1. Hypothermia.

a. Exposure to cold.

b. Hypothyroidism.

2. Fever.

a. Tetanus toxin.

b. Thyroid vaccine.

c. Heat injury: heat cramps, heat exhaustion, heat stroke.

d. Malignant hyperthermia.

e. Malignant neuroleptic syndrome.

G. Infections

1. Viral: Influenza $A$, influenza $B$, herpes simplex; infectious mononucleosis; coxsackie.

2. Bacterial: typhoid fever; E. coli sepsis.

3. Other Organisms: Legionnaire's disease; mycoplasma.

4. Toxic shock syndrome.

H. Progressive Muscle Disease

1. Polymyositis.

2. Dermatomyositis.

I. Cause Unknown 
Another conundrum is exemplified by carnitine palmityl transferase deficiency. The enzyme is necessary for the transport of long-chain fatty acids into mitochondria and subsequent oxidation. Transport is possible only after the fatty acid has been esterified with carnitine. Deficiency of either substrate or enzyme should have similar consequences. In fact, however, loss of the enzyme results in a syndrome of recurrent myoglobinuria while loss of carnitine results in a lipid storage myopathy that is manifest by limb weakness, with no myoglobinuria. Why the syndromes should differ remains a mystery.

The glycogen diseases have also raised similar conundrums; some are manifest by recurrent myoglobinuria, others by limb weakness, and some by both (Rowland and DiMauro, 1983). These differences are also unexplained.

Although progress has been made in identifying the biochemical causes of hereditable myoglobinuria, there are still unidentified cases. In some families, more than one person has had attacks of myoglobinuria but all tests for known enzyme abnormalities give normal values; similarly, even if no other family member is affected, heredity causes may be suspected when a patient has repeated attacks (Christensen et al., 1982; McNaught et al., 1974). Among the cases of unidentified causes were a pair of twins with recurrent myoglobinuria; although Engel et al. (1970) predicted lack of carnitine palmityl transferase activity, that enzyme activity was normal when it was assayed by DiMauro (1979). Another pair of brothers had single episodes of myoglobinuria with influenza (Zamkoff and Rosen, 1979); the familial incidence seemed tied to exposure to the same viral agent but the patients were not tested for known enzyme disorders.

\section{Malignant Hyperthermia: A Special Problem}

Malignant hyperthermia is another condition that is held to be hereditary (Denborough and Lovell, 1960), but there is serious question about this. It is stated that $50 \%$ of cases are inherited as an autosomal dominant trait (Britt et al., 1969; McPherson and Taylor, 1982). However, there have been few families in which fully affected individuals presented the evidence of transmission; in these families there was more than one person who actually had an attack, but the number of family members so affected was never sufficient to suggest any mode of transmission. In most families some other "market" was used to identify "affected" individuals. Often this marker was merely a serum CK level above an arbitrarily established upper limit (Kelstrup et al., 1973; Plotz, 1980); less often, a physiologic test was used to identify "susceptible"' individuals.

The validity of these markers has not been established. Normal serum CK values are found in at least $20 \%$ of those who survive MH attacks; there are false negatives. There are undoubtedly false positives, too, because control populations were not usually studied simultaneously with the family at risk and there is no way of validating the implications of an "abnormal" test result except by putting the individual to the risk of general anesthesia. Understandably, this has not been done deliberately but many operations have been done on patients with abnormal serum CK (Owen and Kerry, 1977).

Similarly, the numerous physiologic tests have not been standardized. The most popular tests are tension responses of excised strips of muscle to halothane, caffeine, or both; survivors of MH attacks seem abnormally sensitive to these agents. It is implied that at least one of these three tests will give an abnormal result in any survivor of $\mathrm{MH}$ and that there are no false negatives
(Nelson and Flewellen, 1983). This conclusion seems dubious because the most accurate test or combination of tests has not been the same in all reports. That there are false positives also seems likely; in one study $15 \%$ of the local population was deemed to be "MH-susceptible" (Nelson et al., 1983). Biochemical tests have also been used; the activity of adenylate cyclase, the content of CAMP, and the proportion of phosphorylase a are all increased in muscle of $\mathrm{MH}$ survivors (Willner et al., 1979, 1980, 1981).

For many reasons, $\mathrm{MH}$ seems to be a syndrome of diverse etiology, only rarely genetic. The evidence includes the following:

1. It is difficult to define the syndrome. Fully expressed, it includes rapid rise in body temperature; "rigidity" of masseter and limb muscles; metabolic acidosis; tachycardia and arrhythmias; and myoglobinuria (Britt et al., 1969; Gronert, 1980; Rutberg et al., 1983). Problems arise when one or more of the major characteristics is missing (Flewellen and Nelson, 1983; Kripke et al., 1982). It is stated that rigidity is not seen in $20 \%$ of acceptable cases (Britt and Kalow, 1970) and even fever may be lacking (Bernardt and Horder, 1978). If a child develops masseter rigidity at the start of general anesthesia and then there is no fever because cooling measures are promptly instituted (Carballo, 1975; Caseby, 1975; Davis, 1977, Donlon et al., 1978; Dodd et al., 1981; Inoue et al., 1977; Jago and Payne, 1977; Schmitt et al., 1975), was this an aborted attack of MH or some other kind of reaction to succinylocholine? It is clear that fullblown attacks of $\mathrm{MH}$ may start with masseter spasm and there have been cases of masseter spasm alone or with myoglobinuria but no other manifestations of $\mathrm{MH}$; not all of these patients have "positive"' tests for MH-susceptibility (Flewellen and Nelson, 1982). Similarly, Willner and Nakagawa (in press) believe that the anesthesia-induced myoglobinuric syndrome of boys with Duchenne dystrophy is not $\mathrm{MH}$ because fever and tachycardia are often lacking. However, there are many similarities of the Duchenne syndrome to MH (Rowland, 1983; McKishnie et al., 1983).

Even if a broad view were taken, that any one of the major criteria were sufficient to identify $\mathrm{MH}$, there would still be problems. Serum enzyme and myoglobin levels commonly rise after administration of succinylcholine (Lewandowski, 1981); what level would define MH? How much tachycardia or arrhythmia would suffice? Is cardiac arrest a permissible manifestation if there is no preceding tachycardia? How much rise in temperature is necessary to qualify? Is any degree of masseter spasm sufficient? Are all cases of anesthesia-induced myoglobinuria (Bernhardt and Horder, 1978; Chaboche et al., 1982) manifestations of some form of $\mathrm{MH}$ ? It is possible to state that any person is not $\mathrm{MH}$-susceptible? One patient had an attack after 12 uneventful operations under general anesthesia (Puschel et al., 1978).

2. As stated above, the clinical genetic evidence is weak. When more than one case of such a rare condition appears in a family a genetic basis may be suspected. But when so many cases are sporadic, multifactorial inheritance seems likely (Ellis et al., 1978) or the condition may be heterogeneous, comprising different disorders. Willner and Nakagawa found that only 2 of 50 survivors of $\mathrm{MH}$ attacks had a relative who had also experienced an attack. Halsall et al. (1979) encountered no MH attacks when general anesthesia was given to 321 relatives of $\mathrm{MH}$ patients. Moreover, there has been no clear evidence what the biochemical disorder might be. The generally accepted 
theory (Gronert, 1980; Nelson and Flewellen, 1983) is that the abnormal gene product affects the function of sarcoplasmic reticulum, which then becomes susceptible to activities of the anesthetics that inhibit binding of calcium; the resulting increased cytoplasmic level of calcium would then be responsible for the muscle stiffness and hypermetabolic state of muscle.

However, there is evidence that sarcolemma is also abnormal in some if not all cases (Gronert, 1980; Halsall and Ellis, 1983). An abnormality of adenylate cyclase was first taken to be an indication of sarcolemmal abnormality (Willner et al., 1979, 1981) but there is evidence that this enzyme may also be found in sarcoplasmic reticulum (Willner, personal communication). Abnormality of function in "skinned" single fibers also implies that the sarcolemma cannot be the primary abnormality in those cases (Takagi et al., 1976; Wood et al., 1979).

3. Among the genetic causes of $\mathrm{MH}$ are identifiable disorders such as myotonia congenita, myotonic muscular dystrophy, Duchenne muscular dystrophy, Schwartz-Jampel syndrome (chondrodystrophic myotonia), the King syndrome (a combination of skeletal abnormalities and static myopathy) (King and Denborough, 1973; Kaplan et al., 1977; McPherson and Taylor, 1981), and central core disease (Frank et al., 1980). The diversity of hereditable conditions implies that there is no single cause; the disproportionately large number of cases of Duchenne dystrophy and central core disease suggests that these conditions actually predispose to $\mathrm{MH}$ and, that these two associations are not merely fortuitous.

4. The clinical manifestations of $\mathbf{M H}$ are almost identical to those of the "neuroleptic malignant syndrome (NMS) (Eiser et al., 1982; Smego and Duralk, 1982), including fever, acidosis, rigidity, myoglobinuria and relief by dantrolene (Kolb et al., 1982; Day et al., 1983; Gouldon et al., 1983). The only difference is that $\mathrm{MH}$ is a more acute disorder, with a more easily defined onset and a usually brief course that is measured in hours whereas MNS starts gradually and lasts days or weeks (Table 4).

Despite the similarities, NMS and MH have been considered different because no individual has yet had both disorders (as might be expected if the same genetic biochemical disorder made a person susceptible), and at least one survivor of MNS later had general anesthesia without incident (Lostra et al., 1983). Similarly, the two conditions have not appeared in the same family and the physiologic or biochemical tests for $\mathrm{MH}$-susceptibility have been negative in some survivors of
MNS (Tollefson, 1982; Burke et al., 1981). Moreover, there is evidence of cerebral disorder in MNS (Henderson and Wooten, 1981) and bromocriptine therapy has had apparent benefit (DhibJahlbut et al., 1983; Mueller et al., 1983; Granato et al., 1983). However, Caroff et al., (1983) found that excised muscle from one MNS-survivor was sensitive to both halothane and fluphenazine. The relationship of MNS and $\mathrm{MH}$ is therefore uncertain but the bulk of evidence suggests that they differ.

"Heat stroke" is another disorder with similar manifestations (Jardon, 1982); the diagnostic criteria include metabolic encephalopathy, anhydrosis, and hyperpyrexia(Clowes and O'Donnell, 1974; O'Donnell, 1975) but myoglobinuria is probably a regular feature and dantrolene has therefore been used to treat heat stroke, too (Lydiatt and Hill, 1981). Toxic shock syndrome is still another disorder that incorporates fever and myoglobinuria, with additional essential components of fall in blood pressure, desquamating rash, thrombocytopenia, encephalopathy, liver disease and renal disease (Clayton et al., 1982); little wonder that it is sometimes difficult to classify individual cases (Mason and Thomas, 1976). Disseminated intravenous coagulopathy occurs in $\mathrm{MH}$ and all of the other heat-related syndromes. Only in $\mathrm{MH}$ has genetics been implicated.

These arguments about the genetics of $\mathrm{MH}$ have some practical implications. It seems unlikely that there will be a single cause of "MH myopathy". Therefore, it seems unlikely that reliable methods will be developed to identify all relatives at risk once a proband has been recognized. Alternatively, all first-degree relatives should probably be deemed potentially susceptible and wear a warning bracelet so that anesthesiologists could be forewarned in case of emergency. In this public relations problem, the name of the condition seems a double handicap. "Hyperthermia" is limited because fever is not always present and "malignant" raises questions about cancer to unsophisticated families. An eponym (such as Denborough-Britt-Kalow syndrome) would be appropriately inexact.

\section{SPORADIC (ACQUIRED) FORMS OF MYOGLOBINURIA}

Exertion: The causes of acquired myoglobinuria are numerous and diverse (Tables $2,3,4,5,6,7$ ). They probably overlap with genetic causes because some patients with glycogen storage disease, for instance, are first brought to light by an exerciseinduced attack of myoglobinuria. These cases are few but another, possibly genetic, question is raised. If hundreds of military

\section{Table 4: Heat, Fever and Myoglobinurla:}



*Herditable biochemical abnormality may be identified. 
recruits are put to strenuous exercise, why do only one or two have attacks of myoglobinuria? If thousands of runners complete a marathon race, why do only one or two have attacks of myoglobinuria? Are these people unusually susceptible in some way that has not yet been recognized? Does "metabolic exhaustion" link the sporadic cases to the hereditable conditions?

Genetic susceptibility is not thought to be responsible for most exercise-induced attacks. Rather it is widely believed that any one, stressed sufficiently, might have an attack of myoglobinuria (Gitlin and Demos, 1974). Why this should be is not known, and the term "rhabdomyolysis" merely hides our ignorance. We do not know whether muscle is injured by trauma (running downhill is more traumatic than level running) (Friden et al., 1981; Hikida et al., 1983; Schwane et al., 1983), by ischemia in prolonged isometric contraction, by metabolic exhaustion or other biochemical alterations in prolonged running, by distorted heat regulation or blood flow, by hypokalemia and resulting adverse effects on muscle circulation (Knochel, 1978), or even by unsuspected viral infections in some subjects. By all of the above? Or none of the above? Patients with sickle cell trait may be at special risk (Helzlouer et al., 1983).

The sports medicine literature increases progressively but there seems to be a contradiction in advice to runners and workers who are exposed to high ambient temperatures. Workers are instructed to take salt when they drink water; runners are told to drink water without salt (and, also, to sprinkle water frequently) (American College of Sports Medicine, 1975). Yet this difference cannot be cause of myoglobinuria in runners because so few attacks occur among those who take no salt (Bar-Sela et al., 1979; Brooke et al., 1979; Bunch, 1980; Demos and Gitlen 1974; Maxwell and Bloor, 1981; MacSearraigh et al., 1979; Melamed et al., 19782; Olerud et al., 1976; Ross et al., 1983; Schiff et al., 1978; Wyndham and Strydom 1969).

It seems clear that training protects muscle against exerciseinduced injury (Ross et al., 1983) but how this occurs is not clear except that fiber types tend to become more "oxidative" than "glycolytic" and mitochondria proliferate. Cardiovascular changes must also play a role in feats of endurance. Also, in some military cases and many marathon cases, lack of training seemed to be exonerated. Among experienced runners, attacks seemed more likely to occur when the competitors set unrealistic expectations for speed or distance, and when they were exposed to high ambient temperatures (England et al., 1982). Dietary modifications in training did not seem important (Bank, 1977). Many cases of myoglobinuria in runners have also had features of heat stroke (defined by the combination of altered consciousness, hemoconcentration and lack of sweating) (Beard et al., 1979; Knochel, 1974; Sprung et al., 1980). In this respect, the syndrome differs from that of "heat cramps", which is attributed to drinking water without salt while sweating profusely; the result is hemodilution and hyponatremia. "Heat exhaustion" is the intermediate syndrome, with hemoconcentration and malaise but without the alterations of consciousness and disappearance of sweating of heat stroke. In fact, myoglobinuria has occurred in all three heat conditions (and they are not always easy to separate) (Rowland and Penn, 1972, 1974). Fever may therefore play a causal role in runner's myoglobinuria but the widespread muscle injury of an attack might even cause the fever, rather than the reverse. In the elderly, exposure to an environmental heat wave, without undue exercise, may suffice to induce heat stroke and myoglobinuria (Kilbourn et al., 1982; Kim et al., 1980.
Exertion also seems to be a factor in some other forms of myoglobinuria, not only strenuous athletics such as wrestling or skiing, but status epilepticus, status asthmaticus (Chugh et al., 1978), or struggling against restraints (Goode and Meltzer, 1976; Goode et al., 1977; Rowland and Penn, 1972). Exertion may also be a factor after the convulsions of lightning or electric shock (Braasch and Demaso, 1980), or after some drugs (such as amphetamines, phencyclidine, strychnine, water hemlock) (Abreo et al., 1982; Barton et al., 1980; Boyd et al., 1983; Carlton et al., 1979; Kendrick et al., 1977; Skjoto et al., 1979; Swenson et al., 1982; Unger et al., 1982), in drug-induced dystonia (Jankovic and Penn, 1982), or prolonged myoclonus in viral encephalomyelitis (Langston et al., 1977). However, drugs or electricity may have more direct effects on muscle (Undterdorfer and Lederer, 1975).

\section{Crush and Ischemic Injury:}

These two forms of muscle injury can be discussed together because they clearly involve common mechanisms. Crush injury may directly compress and injure muscle; it also compresses intramuscular blood vessels and larger vessels to make ischemia part of the process. Swelling of the muscle within a fascial compartment may aggravate the injury (Mubarak and Owen, 1975; Owen et al., 1979). On the other hand, if a major artery is suddenly occluded, the muscle it serves will become necrotic and edematous and the edema, itself, further compresses small arteries. In one remarkable case, edema of the legs followed ligation of the inferior vena cava; the edema was so severe that the already marginal circulation of the patient's legs was further compromised and myoglobinuria resulted (Olivero and Ayus, 1978). We have already seen that the circumstances of crush injury in comatose patients are likely to threaten renal function; the edema and prolonged immobility are also likely to lead to pressure palsies or traction injuries of peripheral nerves; the resulting paralysis may prolong the state of immobility and, therefore, the crust (Cadnapaphornchal et al., 1980; Penn et al., 1972). Similar consequences may result from prolonged immobility during anesthesia and surgery (Larcan et al., 1980). Again, interference with the energy metabolism of muscle seems to be compromised. Epsilon aminocaproic acid (Britt et al., 1980) is thought to cause myoglobinuria by enhancing clotting in small intramuscular vessels but this has not been proven. Fibrin thrombi also occlude these vessels in the hemolytic-uremic syndrome (Andreoli and Bergstein, 1983) and may be important in the disseminated invascular coagulation of the heat syndromes. Ischemia could also have been important in the case of myoglobinuria caused by intravenous infection of peanut oil (Lynn, 1975).

\section{Metabolic Depression:}

Cerebral depressants may affect muscle directly, or may affect muscle secondarily when cardiorespiratory responses fail (Table 5). Cellular metabolism may also be distorted by diabetic acidosis (Buckingham et al., 1981), nonketotic hyperglycemia (Rumpf et al., 1981), hypothyroidism (Halverson et al.,), and hypothermia (Raifman et al., 1978; Rosenthal et al., 1981). Hypothyroidism may affect muscle directly or through hypothermia.

For other metabolic anomalies, the effect on cellular energy metabolism is even more unclear. For instance, fever itself may 


\begin{tabular}{|c|c|c|c|}
\hline Mechanism & \multicolumn{2}{|c|}{$\underline{\text { Drugs }}$} & Toxins or Metabolism Disorders \\
\hline Metabolic Depression & \multicolumn{2}{|c|}{$\begin{array}{l}\text { Barbiturates (and other sedatives) } \\
\text { Carbon monoxide } \\
\text { Ethanol } \\
\text { Fenfluramine } \\
\text { Tricyclic antidepressants } \\
\text { Gluetethemide }\end{array}$} & $\begin{array}{l}\text { Hypothyroidism } \\
\text { Diabetic acidosis } \\
\text { Nonketotic hyperglycemia } \\
\text { Hyperosmolarity } \\
\text { Hypernatremia }\end{array}$ \\
\hline Hypokalemia & \multicolumn{2}{|c|}{$\begin{array}{l}\text { Amphotericin } \\
\text { Carbenoxolone } \\
\text { Glycyrrhizate (Licorice) } \\
\text { Thiazides, other kaluretics } \\
\text { Laxative abuse }\end{array}$} & $\begin{array}{l}\text { Diarrhea } \\
\text { Hyperaldosteronism } \\
\text { Renal tubular acidosis }\end{array}$ \\
\hline Hypophosphatemia & & & $\begin{array}{l}\text { Parenteral fluids for acute alcoholism } \\
\text { Diabetic keteoacidosis } \\
\text { Parathyroidectomy }\end{array}$ \\
\hline Ischemia & \multicolumn{2}{|c|}{$\begin{array}{l}\text { Epsilon Aminocaproic Acid } \\
\text { Peanut oil (intravenous) }\end{array}$} & $\begin{array}{l}\text { Total parenteral nutrition } \\
\text { Air embolism }\end{array}$ \\
\hline $\begin{array}{l}\text { Direct Membrane } \\
\text { Effect (?) }\end{array}$ & \multicolumn{2}{|l|}{$\begin{array}{l}\text { Clofibrate } \\
\text { Bezafibrate } \\
\text { Toluene }\end{array}$} & $\begin{array}{c}\text { Venoms: hornet } \\
\text { mulga snake } \\
\text { tiger snake } \\
\text { sea snake }\end{array}$ \\
\hline Agitation or Convulsions & $\begin{array}{l}\text { Amphetamines } \\
\text { Amoxapine } \\
\text { Lithium } \\
\text { Loxapine } \\
\text { Paracetamol } \\
\text { Phencyclidine } \\
\text { Phenylpropanol }\end{array}$ & $\begin{array}{l}\text { Salicylates } \\
\text { Strychnine } \\
\text { Water Hemlock } \\
\text { Mercuric-Chloride }\end{array}$ & $\begin{array}{l}\text { Electroconvulsive therapy } \\
\text { Tetanus } \\
\text { Myoclonus (prolonged) } \\
\text { Dystonia }\end{array}$ \\
\hline $\begin{array}{l}\text { Extremes of Body Temperature } \\
\text { Hypothermia }\end{array}$ & & & $\begin{array}{l}\text { Exposure } \\
\text { Hypthyroidism }\end{array}$ \\
\hline Fever & & & $\begin{array}{l}\text { Tetanus toxin } \\
\text { Typhoid vaccine } \\
\text { Heat cramps } \\
\text { Heat exhaustion } \\
\text { Heat stroke }\end{array}$ \\
\hline
\end{tabular}

* Original citations are given in earlier reviews (Rowland and Penn, 1972; Penn, 1979; Gabow et al., 1982). New drugs and toxins continue to appear (Abreo et al., 1982; Boyd 1983; Swenson et al., 1982; Unger et al., 1982).

be responsible alone (Berg and Frenkel, 1958) or as part of more complicated sepsis (Henrich et al., 1980; Kalish et al., 1982; Nahas et al., 1983); sepsis may be important even in newborns (Gilboa and Swenson, 1976; Haftel et al., 1976). Chronic hypokalemia can cause a chronic myopathy that is manifest by increased serum enzymes alone, prolonged proximal limb weakness, or acute myoglobinuria (Altenwerth, 1982; Dominic et al., 1978; Knochel and Schlein, 1979; Nadel et al., 1979) (Table 6). Similar stages of myopathy are seen in hypothyroidism, with the additional complication of hypothermia; serum enzymes and myoglobin may rise in hypothyroidism with little or no histologic change in muscle. Chronic alcoholism may cause persistent myopathy and attacks of myoglobinuria may be superimposed on this chronic myopathy (Fahlgren et al., 1957); poor nutrition has been blamed on the basis of experimental evidence (Haller and Drachman, 1980). Whatever the mechanism, chronic alcoholism is prominent on the list of causes of myoglobinuria in all large series (Pariente et al., 1983). For reasons not known, alcoholic patients with myoglobinuria only rarely have cardiomyopathy (Rowland and Penn, 1972; Senevirante, 1975).

\section{Membrane Myotoxins}

Few agents seem to attack muscle membranes directly. Most dramatic are the toxins of snakes (Furtado and Lester 1968; Rowland et al., 1969) or insects (Owenby and Odell, 1983) but the mechanisms of action are not known. Among the drugs, clofibrate and similar drugs may be most likely to affect the lipid composition of muscle surface membranes, but the mechanism of action is not known (Bock, 1981; Heidemann et al., 1981; Schneider et al., 1980). Myoglobinuria may follow use of heroin, without coma, but it is not clear whether the responsible agent is heroin itself or some adulterant and it is not known how the muscle injury arises (D'Agostino and Arnett, 1979). Similarly, the nature of the toxic effect is sepsis or toxic shock (Clayton et al., 1982) is not known. 


\section{Table 6: Causes of Hypokalemic Myoglobinuria}
1. Drug therapy
2. Licorice ingestion
3. Alcoholism

Diuretics, carbenoxolene, amphotericin B

Pseudohypoaldosteronism

Dietary deficiency, diarrhea, rehydration and administration of glucose without salt replacement

4. Gastro-intestinal potassium Regional enteritis with steroid loss

therapy

Laxative abuse

Nutritional deficiency

syndromes with diarrhea

Gastric drainage

\section{Total parenteral nutrition \\ 6. Renal tubular acidosis \\ 7. Exercise in hot weather}

From Dominic (1978); Nadel et al (1979)

\section{Progressive Muscle Disease}

Increased serum activity of sarcoplasmic enzymes is one of the major diagnostic signs of myopathy, regardless of cause or classification. It might therefore be expected that patients with chronic myopathy would be more susceptible to attacks of overt myoglobinuria, a new insult adding to the old. Yet this has only rarely been reported. In their classic monograph on polymyositis, Walton and Adams (1954) included cases of acute myoglobinuria; there had been a few earlier cases (Gunther, 1924; Paul, 1924) and there have been several since (Kagen, 1971; Korz and Velz-Boers, 1974; Skrabal et al., 1972; Sloan et al., 1978; Wynne et al., 1977). In these cases, limb weakness was sometimes severe and respiratory muscles were affected in a few cases (Wynne et al., 1977). If the patients recovered in weeks or months and there was no permanent muscle disease. Ostensen et al. (1980) recorded penicillamine-induced myopathy with myoglobinuria at the onset.

It is difficult to know how to classify these cases. Some could have been due to viral-induced myoglobinuria; some were idiopathic in the sense that search for common viruses was negative (Wynne et al., 1977) but negative search does not exclude the possibility of infection. Some were diagnosed as polymyositis because there were inflammatory cells in the muscle, but that histologic change can occur in attacks of myoglobinuria due to any cause, including marathon running (Hkida et al., 1983). The term "polymyositis" seems formally justified, but this acute disorder with myoglobinuria is not the same as the subacute myopathy that usually warrants the designation of polymyositis.

In only a few cases was there evidence of longer-lasting myopathy. For instance, the patient of Gamboa et al. (1979) had gait disorder for several months before an attack of myoglobinuria attributed to influenza virus. Kreitzer et al. (1978) described a man with limb weakness for a year; he was treated with prednisone for four months before an episode of myoglobinuria. Marks et al. (1976) described a patient with drug-induced coma and myoglobinuria. On discharge, two months later, there was still weakness and wasting of leg muscles (with sensory loss, too); one week later the patient returned to the hospital with periorbital edema and erythema, new weakness of arm and cranial muscles,
Grotton's patches, subcutaneous edema over the shoulders and a new rise of serum enzymes. The picture seemed to be that of dermatomyositis, but Knochel (1982) has attributed eyelid edema in myoglobinuria to loss of serum albumin, and we have reported lid edema in otherwise uncomplicated myoglobinuria (Rowland and Penn, 1972). Kessler et al. (1972) described a patient with an acute myoglobinuric syndrome of rash and edema thought to be compatible with dermatomyositis; the patient died of respiratory failure within two months.

In another case, Pirovino et al. (1979) described myoglobinuria after a syndrome of fever, arthralgia and limb weakness for one month, with gradual improvement in another month. Carleton et al. (1977) presented a patient with a syndrome of myoglobinuria and histologic changes of glomerulonephritis; they attributed both renal and muscle lesions to a hypothetical virus but the syndrome could have been due to thiazide-induced hypokalemia that was evident in the record.

These cases suggest overlap with the ill-defined syndrome of polymyositis, but there has been no case of progressive muscular dystrophy with myoglobinuria except after the anesthetic catastrophes described above, in relation to malignant hyperthermia.

\section{Infections}

Myalgia has long been recognized as a symptom of influenza virus infection. Masson and Keller (1975) found that CK was high in the acute phase serum samples from children with serologically-proven infection, but the $\mathrm{CK}$ values returned to normal in convalescent serum. It is therefore not surprising that some cases of myoglobinuria are also associated with serological evidence of influenza virus infection (Canaud et al., 1983; Cunningham et al., 1979; Minow et al., 1974; Morgensen, 1974) and that virus has actually been isolated from muscle (Gamboa et al., 1979). How the virus causes either polymyositis or myoglobinuria is not clear but it is not restricted to influenza virus. Among other viruses incriminated in attacks of myoglobinuria are herpes group (Schlesinger et al., 1978); enterovirus (Jehn et al.), mononucleosis (Kanter et al., 1978), and Legionnaires' disease (Posner et al., 1980). Bacterial infections include typhoid (Rheingold et al., 1976); and E. coli (Henrich et al., 1980), or multiple organisms (Kalish et al., 1982; Nahas et al., 1983) mycoplasma (Rothstein and Kenny, 1979) has also been incriminated. The role of fever in these cases is uncertain.

This toxic shock syndrome, attributed to staphylococcal toxin was defined by Todd et al. (1978). The clinical criteria include: hypotension, fever, erythematous rash, involvement of at least four organ systems, and no other cause. The four organ systems include liver, kidney, brain and muscle. Although myopathy has not been emphasized, the data from every series indicate that it can be a major aspect of the disorder (Shands et al., 1980), and myoglobinuria may play a role in renal failure. Among 11 patients at the Mayo Clinic, all had myalgia; myoglobinuria was documented in two cases and myoglobinemia in another. Serum CK was more than 1000 in those three cases and also in a fourth (McKenna et al., 1980).

\section{Concomitants and Consequences of Myoglobinuria}

It has been calculated that clinical myoglobinuria can result from destruction of about 200 grams of skeletal muscle. It is presumed that all constituents of the destroyed muscle are discharged into the blood. The circumstances that cause this 
catastrophe are also likely to cause dehydration, shock, or acidosis, the conditions that make heme-induced nephropathy more likely (Braun et al., 1976; Knochel, 1976, 1982; Koffler et al., 1976). Renal failure was seen in $33 \%$ of the cases of Gabow et al. (1982) but this figure may be exaggerated because renal failure often calls attention to myoglobinuria.

The combination of increased entry and decreased exit of sarcoplasmic components causes rapidly increasing plasma levels of creatinine, potassium, phosphate and urate; the resulting metabolic aberrations may have additional adverse affects on kidneys and heart (Knochel 1976; Warren et al., 1975). Changes in calcium metabolism may be prominent, with hypocalcemia at first attributed to hyperphosphatemia and, later, hypercalcemia. These changes involve altered secretion of parathormone and Vitamin D, with sequential deposition and resorption of calcium in injured muscle (Akmal et al., 1976; Knochel, 1982).

As complicated as these changes may be, the administration of mannitol or other osmotic diuretics can often prevent renal failure (Eneas et al., 1979). Often, however, renal failure requires dialysis. Myoglobin itself is not dialyzable (Hart et al., 1982) and plasmapheresis has been used (Kuroda et al., 1981). With proper treatment, the prognosis should be good but some fatalities result because of the precarious general condition of many of these patients; 6 of 29 patients with renal failure died in the series of Gabow et al. (1982). Fasciotomy has been used to relieve muscle swelling and pressure in compartmental syndromes (Chaikan, 1980; Owen et al., 1979).

Among survivors, there have been no convincing examples of either permanent renal disease (McCarron et al., 1980) or permanent myopathy, even though both might be anticipated. Nerve injuries, however, are too often seen in survivors of coma-crush myoglobinuria (Akmal and Massry, 1983; Chaiken, 1980; Penn et al., 1972).

\section{REFERENCES}

Abreo, K., Shelp, W.D., Kosseff, A., Thomas, S. (1982). Amoxapineassociate rhabdomyolysis and acute renal failure: case report. $\mathrm{J}$. Clin. Psychiatry 43:426-427.

Adams, E.C., Layman, K.M., Jaunakais, I. (1978). Radioimmunoassay for serum myoglobin. Ann. Clin. Lab. Sci. 8:339-341.

Akmal, M., Goldstein, D.A., Telfer, N. et al. (1976). Resolution of muscle calcification in rhabdomyolysis and acute renal failure. Ann. Intern. Med. 85:23-28.

Akmal, M., Massry, S.G. (1983). Peripheral nerve damage with nontraumatic rhabdomyolysis. Arch. Int. Med. 143:835-837.

Altenwerth, F.J. (1982). Rhabdomyolyse durch Hypokaliamie? Dsch med Wschr 107:196-197.

American College of Sports Medicine (1975). Position statement on prevention of heat injuries during distance running. Med. Sci. Sports 7:7-9.

Anderson, R.J., Linas, S.L., Berns, A.S. et al. (1977). Nonaliguric acute renal failure. N. Engl. J. Med. 296:1134-1138.

Bank, W.J. (1977). Myoglobinuria in marathon runners: possible relationship to carbohydrate and lipid metabolism. Ann. N.Y. Acad. Sci. 301:942-949.

Bar-Sela, S., Tur-Kaspa, R., Euakim, M. (1979). Rhabdomyolysis and acute renal failure in a marathon runner in Israel. Isr. J. Med. Sci. 15:464-466.

Barton, C.H., Sterling, M.L., Vaziri, N.D. (1980) Rhabdomyolysis and acute renal failure associated with phencyclidine intoxication. JAMA 140:568-569.

Bean, W.B., Eichna, L.W. (1943). Performance in relation to environmental temperatures reactions of normal young men to simulated desert environment. Fed. Proc. 2:144-158.

Beard, M.E.J., Hamer, J.W., Hamilton, G., Maslowski, A.H. (1979). Jogger's heat stroke. N. Zealand M.J. 631:159-161.
Berg, P., Frenkel, E.P. (1958). Myoglobinuria after spontaneous and induced fever: report of a case. Ann Intern. Med. 48:380-389.

Bernhardt, D., Horder, M.H. (1978). Anestheia-induced myoglobinuria without hyperpyrexia - an abortive form of malignant hyperthermia? In Proc. 2nd Int. Symp. Malignant Hyperthermia. Aldrete A., Brit B.R. (Eds.) Grune and Stratton, N.Y.

Bock, K.D. (1981). Acute muscular syndrome after bezafibrate. Klin Wschr. 59:1321.

Bowden, D.H., Fraser, D., Jackson, S.H., Walker, N.F. (1956). Acute recurrent rhabdomyolysis (paroxysmal myohaemoglobinuria). Medicine 35:335-353.

Boyd, R.E., Brennan, P.T., Deng, J.F., Rochester, D.F., Spyker. D.A. (1983). Strychnine poisoning. Recovery from profound lactic acidosis, hyperthermia, rhabdomyolysis. Am. J. Med. 74:507-512.

Braasch, E.R., Demaso, D.R. (1980). Effect of electroconvulsive therapy on serum isoenzymes. Am. J. Psychiat. 137:625-626.

Braun, S.R., Weiss, R.F., Keller, A.L. et al. (1976). Evaluation of the renal toxicity of heme proteins and their derivatives. J. Exper. Med. 131:443-460.

Britt, B.A., Kalow, W. (1970). Malignant hyperthermia. Canad. Anaesth. Soc. J. 17:293-315.

Britt, B.A., Locher, W.G., Kalow, W. (1969). Hereditary aspects of malignant hyperthermia. Canad. Anaes. Soc. J. 16:89-98.

Britt, C.W. Jr., Light, R.R., Peters, B.H., Schochet, S.S. (1980). Rhabdomyolysis during treatment with epsilon-aminocaproic acid. Arch. Neurol 37:187-188.

Brooke, M.H., Carroll, J.E., Hagberg, J.M. (1979). The prolonged exercise test. Neurology 29:636-643.

Brumback, R.A., Gerst, J.W., Knull, H.R. (1983). High energy phosphate depletion in a model of defective muscle glycolysis. Muscle Nerve 6:52-55.

Buckingham, B.A., Roe, T.F., Yoon, J.W. (1981). Rhabdomyolysis in diabetic ketoacidosis. Am. J. Dis. Child 135:352-354.

Bunch, T.W. (1980). Blood test abnormalities in runners. Mayo Clin. Proc. 55:113-117.

Burke, R.E., Fahn, S., Mayeux, R., Weinberg, H., Louis, K., Willner, J.H. (1981). Neuroleptic malignant syndrome caused by dopaminedepleting drugs in a patient with Huntington disease. Neurology 31:1022-1026.

Cadnapaphornchal, P., Taher, S., McDonald, F.D. (1980). Acute drugassociated rhabdomyolysis: and examination of its diverse renal manisfestations and complications. Am. J. Med. Sci. 280:66-72.

Canaud, B., Legendre, C., Beraud, J.J., Mirouze, J. (1983). Rhabdomyolyse aigue au cours d'une grippe " $A$ " maligne. Presse med. 12:299.

Carballo, A.S. (1975). Aborted malignant hyperthermia: case report. Canad. Anaesth. Soc. J. 22:227-229.

Carleton, H., Pitts, W., Davidson, W., Roth, P. (1977). Muscle disease associated with renal failure. Arch. Intern. Med. 137:939-941.

Carlton, B.E., Tufts, E., Girard, D.E. (1979). Water hemlock poisoning complicated by rhabdomyolysis and renal failure. Clin. Toxicol 14:87-92.

Caroff, S., Rosenberg, H., Gerber, J.C. (1983). Neuroleptic malignant syndrome and malignant hyperthermia. Lancet 1:244.

Caseby, N.G. (1975). Muscle hypertonus after intravenous suxamethonium: a clinical problem. Br. J. Anaesth. 47:1101-1105.

Chaboche, C., Nordmann, Y., Fontaine, J.L., Lejeune, C. (1982) Myoglobinurie post-anesthesique. Arch. fr. Pediatr. 39:169-171.

Chaikin, H.L., (1980). Rhabdomyolysis secondary to drug overdose and prolonged coma. South M.J. 73:990-994.

Christensen, T.E., Saxtrup, O., Hansen, T.I., Kristensen, B.H., Beck, B.L., Plesner, T., Krogh, I.M., Andersen, V., Strandgard, S. (1983). Familial myoglobinuria. A study of muscle and kidney pathophysiology in three brothers. Dan. Med. Bull. 30:112-115.

Chugh, K.S., Singhal, P.C., Khatri, G.K. (1978). Rhabdomyolysis and renal failure following status asthmaticus. Chest 73:879-880.

Chugh, K.S., Singhal, P.C., Nath, I.V.S. et al. (1979). Acute renal failure due to nontraumatic rhabdomyolysis. Postgrad Med. J. 55:386-392.

Clayton, A.J., Peacocke, J.E., Ewan, P.E. (1982). Toxic shock syndrome in Canada. Canad. M.A.J. 126:776-779.

Clowes, G.H.A. Jr., O'Donnell, T.F. (1974). Heat stroke. N. Engl. J. Med. 291:364-367.

Cunningham, E., Kohli, R., Venuto, R.C. (1979). Influenza-associated myoglobinuric renal failure. J.A.M.A. 242:2428-2429. 
D'Agostino, R.S., Arnett, E.N. (1979). Acute myoglobinuria and heroin snorting. J.A.M.A. 241:277.

Davis, G.C. (1977). Prolonged muscle rigidity following administration of succinylcholine. South M.J. 70:1139-1140.

Day, D.C., Morris, S.W., Stewart, R.M., Fenton, B.J., Gaffney, F.A. (1983). Neuroleptic malignant syndrome: response to dantrolene sodium. Ann Int. Med. 98:183-184.

DeTorrente, A., Berl, T., Cohn, P.D., Kawamoto, E., Hertz, S., Schrier, R.W. (1976). Hypercalcemia of acute renal failure. Clinical significance and pathogenesis. Am. J. Med. 61:119-123.

Demos, M.A., Gitlin, E.L. (1974). Acute exertional rhabdomyolysis Ann Intern. Med 133:233-239.

Denborough, M.A., Lovell, R.R.H. (1960). Anesthetic deaths in a family. Lancet 2:45.

Dhib-Jahlbut, S., Hesselbrock, R., Brott, T., Silbergeld, D. (1983). Treatment of the neuroleptic malignant syndrome with bromocriptine. J.A.M.A. 250:484-485.

DiMauro, S. (1979). Metabolic myopathies. Handb. Clin. Neurol $41: 175-234$.

DiMauro, S., Dalakas, M., Miranda, A.F. (1983). Phosphoglycerate kinase deficiency: another cause of recurrent myoglobinuria. Ann Neurol. 13:11-19.

DiMauro, S., DiMauro P.M.M. (1973). Muscle carnitine palmityl transferase deficiency and myoglobinuria. Science 182:929-931.

DiMauro, S., Miranda, A.F., Olarte, M., Friedman, R., Hays, A.P. (1982). Muscle phosphoglycerate mutase deficiency. Neurology 32:584-591.

Dodd, M.J., Phattiyakul, P., Silpasuvan, S. (1981). Suspected malignant hyperthermia in a strabismus patient. Arch. Ophthalmol. 99:1247-1250.

Dominic, J.A., Koch, M., Guthrie, G.P. Jr., Galla, J.H. (1978). Primary aldosteronism presenting as myoglobinuric acute renal failure. Arch. Intern. Med. 138:1433-1434.

Donald, T.G., Cloonan, M.J., Wilcken, D.E.L. (1978). Excretion of myoglobin in urine after cardiac catherization. Br. Heart J. 40:1237-1242

Donlon, J.V., Mewfield, P., Sreter, F., Ryan, J.F. (1978). Implications of masseter spasm after succinylcholine. Anesthesiology 49:298-301.

Edwards, R.H., Young, A., Wiles, M. (1980). Needle biopsy of skeletal muscle in the diagnosis of myopathy and the clinical study of muscle functions and repair. N. Engl. J. Med. 302:261-271.

Eiser, A.R., Neff, M.S., Slifkin, R.F. (1982). Acute myoglobinuric renal failure. A consequence of the neuroleptic malignant syndrome. Arch. Int. Med. 142:601-603.

Ellis, R.F., Cain, P.A., Harriman, D.G.F. (1978). Multifactorial inheritance of malignant hyperthermia susceptibility. In 2nd Internat. Symp. on Malignant Hyperthermia. Aldrete, J.A., Britt, B.A., (Eds.). Grune and Stratton, N.Y. pp. 329-338.

Eneas, J.F., Schoenfeld, P.Y., Humphreys, M.H. (1979). The effect of infusion of mannitol-sodium bicarbonate on the clinical course of myoglobinuria. Arch. Intern. Med. 139:801-805.

Engel, W.K., Vick, N.A., Glueck, J., Levi, R.I. (1970). A skeletal muscle disorder associated with intermittent symptoms and a possible defect in lipid metabolism. N. Engl. J. Med. 282:697-704

England, A.C., Fraser, D.W., Hightower, A.W. et al. (1982). Preventing severe heat injury in runners: suggestions from the 1979 Peachtree Toad experience. Ann. Int. Med. 97:196-201.

Fahlgren, H., Hed, R., Lundmark, C. (1957). Myonecrosis and myoglobinuria in alcohol and barbiturate intoxication. Acta. Med. Scandinav. 158:405-412.

Flewellen, E.H., Nelson, T.E. (1982). Masseter spasm induced by succinylcholine in children: contracture testing for malignant hyperthermia: report of six cases. Can. Anaesth. Soc. 29:42-49.

Frank, J.P., Harati, Y., Butler, I.J., Nelson, T.E., Scott, C.L. (1980) Central core disease and malignant hyperthermia syndrome. Ann Neurol. 7:11-17.

Friden, J.M., Sjostrom, M., Ekbom, B. (1981). A morphological study of delayed muscle soreness. Experientia. 37:506-507.

Furtado, M.A., Lester, 1.A. (1968). Myoglobinuria following snakebite. Med. J. Australia 1:674-676.

Gabow, P.A., Kaehny W.D., Kelleher, S.P. (1982). The spectrum of rhabdomyolysis. Medicine 61:141-152.

Gadoth, N., Margalit, D., Shapria, Y. (1978). Myopathy with multiple central cores: a case of hypersensitivity to pyrexia. Neuropaediatrie 9:239-244.
Gamboa, E.T., Eastwood, A.B., Hays, A.P., Maxwell, J., Penn, A.S. (1979). Isolation of influenza virus from muscle in myoglobinuric polymyositis. Neurology 29:1323-1335.

Ghatak, N.R., Ereberg, G., Hirano, A., Golden, G.S. (1973). Idiopathic rhabdomyolysis in children. J. Neurol. Sci. 20:253-268.

Gibbs, J.M. (1978). A case of rhabdomyolysis associated with suxamethonium. Anaesth. Intens. Care 6:141-142.

Gilboa, N., Swanson, J.R. (1976). Serum creatine phosphokinase in normal newborns. Arch. Dis. Child 51:283-285.

Gitlin, E.L., Demos, M.A. (1974). Acute exertional rhabdomyolysis: a syndrome of increasing importance to the military physician. Milit. Med. 139:33-36.

Goode, D.J., Meltzer, H.Y. (1976). Effects of isometric exercise on serum creatine phosphokinase activity. Arch. Gen. Psychiatry 33:1297-1311.

Goode, D.J., Weinberg, D.H., Mazure, T.A., Curtiss, G., Muretti, R.J., Meltzer, H.Y. (1977). Effect of limb restraints on serum creatine phosphokinase activity in normal volunteers. Biol. Psychiat. 12:743-755.

Goulon, M., Rohan-Chabot, P., Elkharrat, D., Gajdos, P., Bismuth, C., Conso, F. (1983). Beneficial effects of dantrolene in the treatment of neuroleptic malignant syndrome: a report of two cases. Neurology 33:516-518.

Granato, J.E., Stern, B.J., Ringel, A., Karim, A.H., Krumholz, A., Coyle, J., Adler, S. (1983). Neuroleptic malignant syndrome: successfu treatment with dantrolene and bromocriptine. Ann. Neurol. 14:89-90.

Gronert, G.A. (1980). Malignant hyperthermia. Anesthesiology 53: 395-423.

Grossman, R.A., Hamilton, R.W., Morse, B.M., Penn, A.S., Goldberg, M. (1974). Nontraumatic rhabdomyolysis and acute renal failure. N. Engl. J. Med. 291:807-811.

Gunther, H. (1924). Kasuistische Mitteilung uber Myositis myoglobinurica. Virchows Arch. Path. Anat. 251:141-149.

Haftel, A.J., Eichner, J., Wilson, M.L. (1978). Myoglobinuric renal failure in a newborn infant. J. Pediatr. 93:1015-1016.

Haller, R.G., Drachman, D.B. (1980). Alcholic rhabdomyolysis: an experimental model in the rat. Science 208:412-415.

Hallgren, R., Karlsson, F.A., Roxin, L.E., Venge, P. (1978). Myoglobin turnover - influence of renal and extrarenal factors. J. Lab. Clin. Med. 91:146-154.

Halsall, P.J., Ellis, F.R. (1983). The control of muscle contracture by the action of dantrolene on the sarcolemma. Acta. Anaesth. Scand. 27:229-232.

Halsall, P.J., Cain, P.A., Ellis, F.R. (1979). Retrospective analysis of anesthetics received by patients before susceptibility to malignant hyperpyrexia was recognized. Br. J. Anaesth. 51:949-954.

Halverson, P.B., Kozin, F., Ryan, L.M., Sulaiman, A.R. (1979), Rhabdomyolysis and renal failure in hypothyroidism. Ann. Intern. Med. 91:57-58.

Hansen, K.N., Bjerre-Kr udsen, J., Brodthagen, U., Jordal, R., Palev, P.E. (1982). Muscle cel' leakage due to long-distance training. Europ. J. Appl. Physiol. 48:17; 188.

Hart, P.M., Feinfeld, D.A., Briscoe, A.M., Nurse, H.M., Hotchkiss, J.L., Thomson, G.E. (1982). The effect of renal failure and hemodialysis on serum and urine myoglobin. Clin. Nephrol. 18:141-143.

Heidemann, H., Bock, K.D., Kreuzfelder, E. (1981). Rhabdomyolysis with acute renal failure due to bezafibrate. Klin. Wschr. 59:413-414.

Helzlsouer, K.J., Kayden, F.G., Rogol, A.D. (1983). Severe metabolic complications in a cross-country runner with sickle cell trait. JAMA 24:777-779.

Henderson, V.W., Wooten, G.F. (1981). Neuroleptic malignant syndrome: a pathogenetic role for dopamine receptor blockade? Neurology 31:132-137.

Henrich, W.L., Prophet, D., Knochel, J.P. (1980). Rhabdomyolysis associated with Escherichia coli septicemia. South. Med. J. 73:936-937.

Hikida, R.S., Staron, R.S., Hagerman, F.C., Sherman, W.M., Costill, D.L. (1983). Muscle fiber necrosis associated with human marathon runners. J. Neurol. Sci. 59:185-203.

Inagaki, M., Koyama, A., Sakata, S. et al. (1980). Serum myoglobin levels following administration of succinylcholine during nitrous oxide-oxygen-halothane anesthesia. Masui 29:1476-1482.

Inoue, R., Kawamata, M., Yamamura, Y., Fujita, M. (1977). Generalized muscular rigidity associated with increased serum enzymes and post-operative muscular weakness induced by general anesthesia without hyperthermia. Hiroshima J. Anesth. 13:232-235. 
Jago, R.J., Payne, M.J. (1977). Malignant hyperpyrexia - the difficulty of diagnosis. Anesthesiology 30:75.

Jankovic, J., Penn, A.S. (1982). Severe dystonia and myoglobinuria. Neurology 32:1195-1197.

Jardon, O.M. (1982). Physiologic stress, heat stroke, malignant hyperthermia - a perspective. Military Med. 147:8-14.

Jehn, U.W., Fink, M.K. (1980). Myositis, myoglobinemia and myoglobinuria associated with enterovirus Echo 9 infection. Arch. Neurol. 37:457-458.

Jensen, K., Rennike, K.A., Hanel, H.K., Olesen, H. (1968). Myoglobinuria following anaesthesia including suxamethonium. Brit. J. Anaesth. 40:329-334.

Johnson, M.D., Baer, R., Katz, A., Shainhouse, Z. (1975). Glomerulonephritis associated with myoglobinuria. Kidney Internat 8:413.

Jones, D.A., Jackson, M.J., Edwards, R.H.T. (1983). Release of intracellular enzymes from an isolated mammalian skeletal muscle preparation. Clin. Sci. 65:193-201.

Kagen, L.J. (1971). Myoglobinemia and myoglobinuria in patients with myositis. Arthr. Rheum. 14:457-464.

Kagen, L.J. (1978). Myoglobin, methods and diagnostic uses. CRC Crit. Rev. Clin. Lab. Sci. 9:273-302.

Kalish, S.B., Tallman, M.S., Cook, F.V., Blumen, E.A. (1982). Polymicrobial septicemia associated with rhabdomyolysis, myoglobinuria and acute renal failure. Arch. Int. Med. 142:133-134.

Kanno, T., Sudo, K., Takeuchi, I., Kanada, S., Honda, N., Nishimura, Y., Oyama, K. (1980). Hereditary deficiency of lactate dehydrogenase M-subunit. Clin. Chim. Acta. 108:267-276.

Kantor, R.J., Norden, C.W., Wein, T.P. (1978). Infectious mononucleosis associated with rhabdomyolysis and renal failure. South. Med. J. 71:346-348

Kaplan, A.M., Beregson, P.S., Gregg, S.A., Curless, R.G. (1977). Malignant hyperthermia associated with myopathy and normal muscle enzymes. J. Pediat. 91:431-434.

Karlsson, F. A., Roxin, L.E., Venge, L., Wibell, L. (1978). Evaluation of urinary myoglobin assay test for myocardial infarction. Scand. J. Clin. Lab. Invest. 38:717-721.

Kelstrup, J., Haase, J., Jorni, J., Reske-Nielsen, E., Hanel, H.K. (1973). Malignant hyperthermia in a family. Acta. Anaesth. Scand. 17:283-284.

Kendrick, W.C., Hull, A.R., Knochel, J.P. (1977). Rhabdomyolysis and shock after intravenous amphetamine administration. Ann. Intern. Med. 86:381-387.

Kessler, E., Weinberger, I., Rosenfeld, J.B. (1972). Myoglobinuric acute renal failure in a case of dermatomyositis. Israel J. Med. Sci. 8:978-983.

Kessler, H.A., Trenholme, G.M., Harris, A.A., Levin, S. (1980). Acute myopathy associated wtih influenza $A / T$ exas/1/77 infection. Isolation of virus from a muscle biopsy specimen. JAMA 243:461-462.

Kilbourne, E. M., Choi K., Jones, S., Thacker, S. B. (1982). Risk factors for heat stroke. A case control study. JAMA 247:3332-3336.

Kim, R.C., Collins, G.H., Cho C., Ichikawa, K., Givelber, H. (1980). Heat stroke. Report of three fatal cases with emphasis on findings in skeletal muscle. Arch. Pathol. Lab. Med. 104:345-349.

King, J.O., Denborough, M.A. (1973). Anesthetic-induced malignant hyperpyrexia in children. J. Pediatr. 83:37-40.

Knochel, J.P. (1974). Environmental heat illness. An eclectic review. Arch. Int. Med. 133:841-864.

Knochel, J.P. (1976). Renal injury in muscle disease. The Kidney in Systemic Disease. Suki, W.N., Eknoyan, G. (Eds). N.Y., John Wiley and Sons, Inc., pp. 129-140.

Knochel, J.P. (1978). Rhabdomyolysis and effects of potassium deficiency on muscle structure and function. Cardiovasc. Med. 3:247-261.

Knochel, J.P. (1982). Rhabdomyolysis and myoglobinuria. Ann. Rev. Med. 33:435-443.

Knochel J.P., Barcenas, C., Cotton, J.R., Fuller, T.J., Haller, R., Carter N.W. (1978). Hypophosphatemia and rhabdomyolysis. J. Clin. Invest. 62:1240-1246.

Knochel, J.P., Schlein, E.M. (1972). On the mechanism of rhabdomyolysis in potassium depletion. J. Clin. Invest. 51:1750-1758.

Koffler, A., Friedler, R.M., Massry, S.G. (1976). Acute renal failure due to nontraumatic rhabdomyolysis. Ann. Int. Med. 85:23-28.

Kolb, M.E., Horne, M.L., Martz, R. (1982). Dantrolene in human malignant hyperthermia. A multicenter study. Anesthesiology $56: 254-262$.
Korz, R., Volz-Boers, U. (1974). Akutes Nierenverseagen nach massiver Myolyse bei pseudomyopathischer Polymyositis. Disch. med. Wschr. 99: 1084-1087.

Kreitzer, S.M., Ehrenpreis, M., Miguel E., Petrasek, J. (1978). Acute myoglobinuric renal failure in polymyositis. New York State J. Med. 78:295-297.

Kripke, B.J., Blanck, T.J.J., Sizemore, D.A., Comunale, F.L., Christiansen, O., Gruener, (1982). Association of post-anesthetic hyperthermia with abnormal muscle characteristics: a case report. Canad. Anaesth. Soc. J. 29:290-294.

Kuroda, M., Katsuki, K., Uehara, H., Kita, T., Asaka, S., Miyazaki. R., Akiyama T., Tofuku, Y., Takeda, R. (1981). Successful treatment of fulminating complications associated with extensive rhabdomyolysis by plasma exchange. Art. Org. 5:372-378.

Langston, J.W., Ricci, D.R., Portlock, C. (1977). Nonhypoxemic hazards of prolonged myoclonus. Neurology 27:542-545.

Larcan, A., Lambert, H., Labprevote-Heully, M.C., Verdaguer, M. (1980). Rhabdomyolyses post-operatoires de cause posturale. Ann. Chir. (Paris) 34:769-774

Lewandowski, K.B. (1981). Rhabdomyolysis, myoglobinuria and hyperpyrexia caused by suxamethonium in a child with increased serum CK concentrations. Br. J. Anaesth. 53:981-984.

Liu E.T., Bristow, M.R., Stone, M.J., Willerson, J.T. (1983). Serum myoglobin, ionized calcium and parathyroid function during rhabdomyolysis. Arch. Inter. Med. 143:154-157.

Llach, F., Felsenfield, A.J., Haussler, M.R. (1981). The pathophysio$\log y$ of altered calcium metabolism in rhabdomyolysis-induced acute renal failure. Interactions of parathyroid hormone. 25-hydroxycholecalciferol and 1,25-dihydroxycholecalciferol. N. Eng. J. Med. 305:117-123.

Lotstra, F., Linkowski, P., Mendlewicz, J. (1983). General anesthesia after neuroleptic malignant syndrome. Biol. Psychiat. 18:243-247.

Lydiatt, J.S., Hill, G.E. (1981). Treatment of heat stroke with dantrolene. JAMA 246:41-42.

Lynn, K.L. (1975). Acute rhabdomyolysis and acute renal failure after intravenous self administration of peanut oil. Brit. M.J. 2:385-386.

MacSearraigh, E.G.M., Kallmeyer J.C.M., Schiff H.B. (1979). Acute renal failure in marathon runners. Nephron. 24:236-240.

Malvano, R., Massaglia, A., Marchisio M. et al. (1978). Radioimmunoassy of circulating human myoglobin. J. Nuc. Med. All Sci. 22:169-175.

Markowitz, H., Wobig, G.H.(1977). Quantitative method for estimating myoglobin in urine. Clin. Chem. 23:1689-1693.

Marks, S.H., McShane, D.J., Mitchell, D.M. (1976). Dermatomyositis following rhabdomyolysis. J. Rheumatol. 3:224-226.

Mason, W., Keller, E. (1975). Acute transient myositis with influenzalike illness. J. Pediat. 86:813-814.

Mason, J., Thomas, E. (1976). Rhabdomyolysis from heat hyperpyrexia Severe hypocalcemia and hypophosphatemia as complicating factors. JAMA 235:633-634

Maxwell, J.H., Bloor, C.M. (1981). Effects of conditioning on exertional rhabdomyolysis and serum creatine kinase after severe exercise. Enzyme 26:177-181.

McCarron, D.A., Royer, K.A., Houghton, D.C., Bennett, W.M. (1980), Chronic tubulointesitial nephritis caused by recurrent myoglobinuria. Arch. Int. Med. 140:1106-1107.

McKenna, U.G., Meadows, J.A. III, Brewser, N.S., Wilson, W.R. Perrault, J. (1980). Toxic shock syndrome, a newly recognized disease entity. Report of 11 cases. Mayo Clin. Proc. 55:663-672.

McKishnie, J.D., Muir, J.M., Girvan, D.P. (1983). Anaesthesia-induced rhabdomyolysis. Can. Aesth. Soc. J. 30:295-298.

McNaught, P., Neale, T.J., Bailey, R.R. (1974). Myoglobinuria in the mountains. New Zealand Med. J. 1:571-575.

McPherson, E.W., Taylor, C.A. Jr. (1981). The King syndrome: malignant hyperthermia, myopathy and multiple anomalies. Am. J. Med. Genet. 8:159-165.

McPherson, E., Taylor, C.A. Jr. (1982). The genetics of malignant hyperthermia: evidence for heterogeneity. Am. J. Med. Genet. $11: 273-285$.

Melamed, I., Romem, Y., Keren, G., Epstein, Y., Dolev, E. (1982). March myoglobinemia. A hazard to renal function. Arch. Intern. Med. 142:1277-1279.

Meyer-Betz, F. (1910). Beobachtungen an einem eigenartigen mit Muskellahmungen verbundenen Fall von Hamoglobinurie. Dsch. Arch. Klin. Med. 101:84-127. 
Minow, R.A., Gorbach, S., Johnson, B.L., Dornfeld, L. (1974). Myoglobinuria associated with influenza A infection. Ann. Int. Med. 80:359-361.

Morgensen, J.L. (1974). Myoglobinuria and renal failure associated with influenza. Ann. Int. Med. 80:362-363.

Mubarak, S., Owen C.A. (1975). Compartmental syndrome and its relation to the crush syndrome, a spectrum of disease. Clin. Orthop. 113:81-89.

Mueller, P.S., Vester, J.W., Fermaglich, J. (1983). Neuroleptic malignant syndrome. Successful treatment with bromocriptine. JAMA 249: 386-388.

Nadel, S.M., Jackson, J.W., Ploth, D.W. (1979). Hypokalemic rhabdomyolysis and acute renal failure. Occurrence following total parenteral nutrition. JAMA 241:2294-2296.

Nahas, A.M.E., Farrington, K., Quyyumi, S., Moorhead, J.F., Sweeney, P. (1983). Rhabdomyolysis and systemic infection. Brit. Med. J. 1:349-350.

Nelson, T.E., Flewellen, E.H. (1983). The malignant hyperthermia syndrome. N. Engl. J. Med. 209:416-418.

Nelson, T.E., Flewellen, E.H., Gloyna, D.F. (1983). Spectrum of susceptibility to malignant hyperthermia: diagnostic dilemma. Anesth. Analg. 62:545-552.

Nicholson, M.R., Somerville, K.W. (1978). Heat stroke in a run for fun. Br. Med. J. 1:1526

O'Donnell, T.F., Jr. (1975). Acute heat stroke. Epidemiologic, biochemical, renal, and coagulation studies. JAMA 234:824-828.

Olerud, J.E., Homer, L.D., Carroll, H.W. (1975). Serum myoglobin levels predicted from serum enzyme levels. N. Engl. J. Med. 293:483-484.

Olerud, J.E., Homer, L.D., Carroll, H.W. (1976). Incidence of acute exertional rhabdomyolysis. Serum myoglobin and enzyme levels as indicators of muscle injury. Arch. Intern. Med. 136:692-697.

Olivero, J., Ayus, J.C. (1978). Rhabdomyolysis and acute myoglobinuric renal failure. Complications of inferior vena cava ligation. Arch. Intern. Med. 138:1548-1549.

Ostensen, M., Husby, G., Aarli, J. (1980). Polymyositis with actue myolysis in a patient with rheumatoid arthritis treated with penicillamine and ampicillin. Arthr. Rheum. 23:375-377.

Ouzounellis, T. (1970). Some notes on quail poisoning. JAMA 211: 1186-1187.

Owen, C.A., Mubarak, S.J., Hargrens, A.R., Rutherford, L., Garetto, L.P., Akeson, W.H. (1979). Intramuscular pressures with limb compression. Clarification of the pathogenesis of drug-induced muscle compartment syndrome. N. Engl. J. Med. 300:1169-1172.

Owen, G., Kerry, R.J. (1974). Anaesthesia during raised creatine phosphokinase activity. Br. M.J. 4:75-76.

Owenby, C.L., Odell, G.V. (1983). Pathogenesis of skeletal muscle necrosis induced by tarantula venom. Exp. Molec. Path. 38:283-296.

Pariente, E.Z., Nouel, O., Bernuau, J., Fraisse, F., Degott, C., Rueff, B. (1983). Rhabdomyolyse aigue chez des malades alcoholiques. Presse. Med., 12:339-343.

Paul, F. (1924). Uker einen Fall von paralytischer Hamoglobinuria beim Menschen. Wien Z. Inn. Med. 7:531-554.

Pellicci, P.M., Paget, S., Tsairis, P. (1983). Postanesthetic myoglobinuria with acute renal failure (normothermic malignant hyperthermia). J. Bone Surg.

Penn, A.S. (1980). Myoglobin and myoglobinuria. Handb. Clin. Neurol. 41:259-285.

Penn, A.S., Rowland, L.P., Fraser, D.W. (1972). Drugs, coma and myoglobinuria. Arch. Neurol. 26:336-343.

Pirovino, M., Neff, M.S., Sharon E. (1979). Myoglobinuria and acute renal failure with actue polymyositis. New York State J. Med. 79:764-767.

Plotz, J. (1980). Maligne Hyperthermie. II Befragung und Untersuchung von Familien mit gliedern einer Erkrankten. Anaesthetist. 29:94-98.

Plotz, J., Braun, J. (1982). Failure of "self-taming" doses of succinylcholine to inhibit increases in postoperative serum creatine kinase activity in children. Anesthesiology 56:207-209.

Posner, M.R., Caudill, M.A., Brass, R., Ellis, E. (1980). Legionaires' disease associated with rhabdomyolysis and myoglobinuria. Arch. Int. Med. 140:848-857.

Puschel, K., Schubert-Thiele, I., Hirth, L., Benkmann, H.G., Brinkmann, B. (1978), Maligne Hyperthermie in der 13. Vollnarkose. Anaesthetist $27: 448-491$
Raifman, M.A., Berant, M., Lenarsky, C. (1978). Cold weather and rhabdomyolysis. J. Pediat. 93:970-971.

Reisin, E., Teicher, A., Jaffe, R., Eliahou, H.E. (1975). Myoglobinuria and renal failure in toluene poisoning. Brit. J. Indust. Med. 32:163-168.

Rheingold, O.J., Greenwald, R.A., Hayes, P.J., Tedesco, F.J. (1977). Myoglobinuria and renal failure associated with typhoid fever. JAMA 23:341.

Robotham, J.L., Haddow, J.E. (1976). Rhabdomyolysis and myoglobinuria in childhood. Pediat. Clin. No. Amer. 23:279-301.

Rosenberg, H., Reed, S. (1983). In vitro contracture tests for susceptibility to malignant hyperthermia. Anesth. Analg. 62:415-420.

Rosenthal, L, Kloiber, R., Gagnon, R., Damtew, B., Lough, J. (1981). Frostbite with rhabdomyolysis and renal failure, radionuclide study. AJR 137:387-390.

Ross, B.D., Radda, G.K., Gadian, D.G., Rocker, G., Esiri, M., Falconer, Smith, B. (1981). Examination of a case of suspected McArdle's syndrome by $31 \mathrm{P}$ nuclear magnetic resonance. N. Engl. J. Med. 304:1338-1342.

Ross, J.H., Attwood, E.C., Atkin, G.E., Villar, R.N. (1983). A study of the effects of severe repetitive exercise on serum myoglobin, creatine kinase, transaminases, and lactate dehydrogenase. Quart J. Med. 52:268-279.

Ross, J.H., Attwood, E.C., Atkin, G.E., Villar, R.N. (1983). A study of the effects of severe repetitive exercise on serum myoglobin, creatine kinase, transaminases and lactate dehydrogenase. Quart J. Med. 52:268-278

Rothstein, T.L., Kenny, G.E. (1979). Cranial neuropathy, myeloradiculopathy, and myositis. Complications of mycoplasma pneumoniae infection. Arch. Neurol. 36:476-477.

Rowland, L.P. (1980). Biochemistry of muscle membrane in Duchenne muscular dystrophy. Muscle Nerve 3:3-20.

Rowland, L.P. (1983). Molecular genetics, pseudogenetics and clinical neurology. Neurology 33:1179-1195.

Rowland, L.P., Araki, S., Carmel, P. (1965). Contracture in McArdle's disease. Stability of ATP during contracture in ATP-deficient muscle. Arch. Neurol. 24:629-644.

Rowland, L.P., DiMauro, S. (1983). Glycogen storage diseases of muscle, genetic problems. Res. Publ. Assoc. Nerv. Ment. Dis. 60:239-254.

Rowland, L.P., Fahn, S., Hirschberg, E., Harter, D.H. (1964). Myoglobinuria. Arch. Neurol. 10:537-562.

Rowland, L.P., Penn, A.S. (1972). Myoglobinuria. Med. Clin. North Am. 56:1233-1256.

Rowland, L.P., Penn, A.S. (1974). Heat-related muscle cramps. Arch. Int. Med. 134:1133.

Rowlands, J.B., Mastaglia, F. L., Kakulas, B.A., Hainsworth, D. (1969). Clinical and pathological aspects of a fatal case of mulga (pseudechis australis) snakebite. Med. J. Australia 1:226-230.

Rumpf, K.W., Kaiser, H., Grone H.J., Trapp, V.E., Meinck, H.M., Goebel, H.H., Kinze, E., Kreuzer, H., Scheler, F. (1981). Myoglobinurisches Nierenversagen bei hyperosmolaren diabetischem Koma. DMW 106:708-711.

Rutberg, H., Henriksson, K-G., Jorgeldt, L., Larsson, J., Martensson, J., Schildt, B. (1983). Metabolic changes in a case of malignant hyperthermia. Brit. J. Anaesth. 55:461-467.

Sararchak, H.J., Bernstein, S.H. (1974). A new diagnostic test for acute myocardial infarction. The detection of myoglobinuria by radioimmunodiffusion assay. JAMA 228:1251-1255.

Schiff, H.B., MacSearraigh, E.T.M., Kallmeyer, J.C. (1978). Myoglobinuria, rhabdomyolysis and marathon running. Quart J. Med. 188:463-472.

Schlesinger, J.J., Gandara, D., Bensen, K.G. (1978). Myoglobinuria associated with herpes group viral infections. Arch. Int. Med. 138:422-424.

Schmidt, R.E., Vogel, J., Gullotta, F., Vogel, F., Bechtelsheimer, H. (1981). Toxische Rhabdomyolyse mit Myokard beteiligung Familiare Disposition. Dsch. Med. Wschr. 106:1458-1462.

Schmitt, H.P., Bersch, W., Feustel, H.P. (1983). Acute abdominal rhabdomyolysis after body building exercise: Is there a "rectus abdominis syndrome'"? Muscle Nerve 6:228-232.

Schmitt, H.P., Simmendinger, J.H., Wagner, H., Volk, B., Busing, C.M., Stenzel, M. (1975). Severe morphological changes in skeletal muscles of a 5-month old infant dying from an anesthetic complication with general muscle rigidity. Syndrome of "malignant hyperpyrexia" without hyperthermia? Neuropadiatrie 6:102-111. 
Schneider, J., Muhlfellner, G., Kaffarnik, H. (1980). Creatine kinase in hyperlipoproteinemic patients treated wtih clofibrate. Artery 8: 164-170.

Schwane, J.A., Johnson, S.R., Vandenakker, C.B., Armstrong, R.B. (1983). Delayed-onset muscular soreness and plasma CPK and LDH activities after downhill running. Med. Sci. Sports Exerc. 15:51-56.

Senevirante, B.I.B. (1975). Acute cardiomyopathy with rhabdomyolysis in chronic acloholism. BMJ 4:378-380.

Sewall, K., Flowerdew, R.M.M., Bromberger, P. (1980). Severe muscular rigidity at birth: malignant hyperthermia syndrome? Canad. Anaesth. Soc. J. 27:279-282.

Shands, K.N., Schmid, G.P., Dan, B.B. et al. (1980). Toxic shock syndrome in menstruating women. Association with tampon use and staphylococcus aureus and clinical features in 52 cases. $\mathrm{N}$. Engl. J. Med. 303:1436-1442.

Skjoto, J., Reikvam, A. (1979). Hyperthermia and rhabdomyolysis in self-poisoning with paracetamol and salicylates. Acta. Med. Scand. 205:473-476.

Skrabal, F., Balogh, D., Dittrich, P. (1972). Akutes Nierenversagen bei Polymyositis. Wien Klin Wschnschr. 84:109.

Sloan, M.F., Franks, A.J., Exley, K.A., Davison, A.M. (1978). Acute renal failure due to polymyositis. Br. Med. J. 1:1457.

Smego, R.A. Jr., Duralk, D.T. (1982). The neuroleptic malignant syndrome. Arch. Intern. Med. 142:1183-1185.

Soffer, O., Fellner, S.K., Rush, R.L. (1981). Creatine phosphokinase in long-term dialysis patients. Arch. Intern. Med. 141:181-183.

Sprung, C.L., Portocarrero, C.J., Fernaine, A.V., Weinberg, P.F. (1980). The metabolic and respiratory alterations of heat stroke. Arch. Intern. Med. 140:665-669.

Stone, M.J., Willerson, J.T., Gomez-Sanchez, C.E. et al. (1975). Radioimmunoassay of myoglobin in human serum. Clin. Invest. 56:1334-1339.

Stringer, J.M., Kainer, R.A., Tu, A.T. (1972). Myonecrosis induced by rattlesnake venom. An electron microscopic study. Am. J. Path. $67: 127-140$.

Swenson, R.D., Golper, T.A., Bennett, W.M. (1982). Acute renal failure and rhabdomyolysis after ingestion of phenylpropanolaminecontaining diet pills. JAMA 248:1216.

Takagi, A., Sugita, H., Toyokura, Y., Endo, M. (1976). Malignant hyperpyrexia. Effect of halothane on single skinned muscle fiber. Proc. Japan Acad. 52:603-606.
Todd, J., Fishaut, M., Kapral, F., Welch, T. (1978). Toxic-shock syndrome associated with phage-group-l-staphylococci. Lancet 2:1116-1118.

Tollefson, G. (1982). A case of neuroleptic malignant syndrome: in vitro muscle comparison with malignant hyperthermia. J. Clin. Psychopharmacol. 2:266-270.

Unger, J., Decaux, G., L'Hermite, M. (1982). Rhabdomyolysis, acute renal failure endocrine alterations and neurological sequelae in a case of lithium self-poisoning. Acta. Clin. Belg. 37:216-223.

Unterdorfer, H., Lederer, B. (1975). Elektrotraumatischer Muskelnekrosen nach Unfallen mit niedergespannten Wechselstrom. Mschr. Unfallheilk 78:333-338.

Walton, J.N., Adams, R.D. (1958). Polymyositis. Williams and Wilkins, Balitmore.

Warren, D.J., Leitch, A.C., Leggett, R.J.E. (1975). Hyperuricaemic acute renal failure after epileptic seizures. Lancet 2:385-387,

Wiliner, J.H., Cerri, C.G., Wood, D.S. (1981). High skeletal muscle adenylate cyclase in malignant hyperthermia. J. Clin. Invest. 68:1119-1124.

Willner, J.H., Nakagawa, M. Controversies in malignant hyperthermia. Semin. Neurol, in press.

Willner J.H., Wood, D.S., Cerri, C., Britt, B. (1980). Increased myophosphorylase-a in malignant hyperthermia. N. Engl. J. Med. 303:138-140.

Willner, J.H., Cerri, C.J., Wood, D.S. (1979). Malignant hyperthermia: abnormal cyclic AMP metabolism in skeletal muscle. Neurology 29:557.

Wood, D.S., Mozo, A., Willner, J.H. (1979). Malignant hyperthermia: relation of sarcoplasmic reticulum to pathogenesis. Neurology 29:557-558.

Wooldridge, T.D., Bower, J.D., Nelson N.C. (1978). Rhabdomyolysis. A complication of parathyroidectomy and calcium supplementation. JAMA 239:643.

Wyndham, C.H., Strydom, N.B. (1969). The danger of an inadequate water intake during marathon running. S. Afr. Med. J. 43:893-896.

Wynne, J.W., Goslen, J.B., Ballinger, W.E. Jr. (1977). Rhabdomyolysis with cardiac and respiratory involvement. South Med. J. 70:1125-1130.

Zamkoff, K., Rosen, N. (1979). Influenza and myoglobinuria in brothers. Neurology 29:340-345. 